\title{
РЕФОРМУВАННЯ ВИЩОЇ ОСВІТИ В УКРАЇНІ
}

\author{
В. В. Шухтін ${ }^{1}$, С. Г. Котюжинська ${ }^{1}$, Т. Л. Лєбєдєва ${ }^{2}$, І. М. Шухтіна ${ }^{1}$ \\ ${ }^{1}$ Одеський національний медичний університет, \\ ${ }^{2} Д П$ “Украӥнський науково-дослідний інститут медицини транспорту МОЗ Украӥни”, Одеса
}

\section{REFORMING OF HIGHER EDUCATION IN UKRAINE}

\author{
V. V. Shukhtin ${ }^{1}$, S. H. Kotiuzhynska1, T. L. Liebiedieva², I. M. Shukhtina1 \\ ${ }^{1}$ Odesa National Medical University, \\ ${ }^{2}$ State Enterprise "Ukrainian Research Institute for Medicine of Transport of Ministry of Health of \\ Ukraine”, Odesa
}

\begin{abstract}
У статті розглянуті основні правові, організаційні, фінансові засади функціонування системи вищої освіти, які створюють умови для поєднання освіти 3 наукою та виробництвом 3 метою підготовки конкурентоспроможного людського капіталу для високотехнологічного та інноваційного розвитку країни, самореалізації особистості, забезпечення потреб суспільства, ринку праці та держави у кваліфікованих фахівцях. Автори статті аналізують ключові проблеми розвитку системи освіти, підвищення якості професійної підготовки фахівців, законодавчого регулювання розвитку системи вищої освіти в Україні в контексті Болонського процесу. Висвітлено стан і перспективи змін освітньої системи України в аспектах використання та вдосконалення різних засобів забезпечення якості навчального процесу і заключних освітніх кваліфікацій. Розглянуто проблемні фактори функціонування вищої освіти України під кутом зору нагальних потреб модернізації вітчизняного освітнього середовища, тобто приведення його у відповідність до імперативних вимог сучасності. Особлива увага приділяється міжнародному співробітництву в галузі освіти, інтеграції національної освіти до міжнародного освітянського простору.
\end{abstract}

The article describes the main legal, institutional, financial frameworks for the higher education system, which create conditions for combining education with science and production with the aim of training competitive human capital for hightech and innovative development, personal fulfillment, meeting the needs of society, the lab our market and the state in qualified specialists. The authors examine key issues in the development of the education system, improving the quality of professional training, legislative regulation of development of higher education in Ukraine in context of Bologna process; highlight the condition and the prospects of change in the educational system of Ukraine in the aspects of the use and improvement of various means to ensure the quality of the educational process and final educational qualifications; consider the problematic factors of the functioning of higher education in Ukraine from the perspective of the immediate needs of modernization of domestic educational environment that is, bringing it into compliance with the imperative requirements of the present. Special attention is paid to international cooperation in the field.

Вступ. За індексом людського розвитку у 2015 році Україна посідала 81 місце серед 186 країн світу [1]. Цей показник вимірює досягнення країни 3 боку стану здоров'я, отримання освіти та фактичного доходу громадян і складається 33 індексів, одним із яких є індекс освіти, який підсумовує доступ до освіти, що вимірюється середньою очікуваною тривалістю навчання дітей шкільного віку і середньою тривалістю навчання дорослого населення. За індексом освіти наша країна у 2013 році посідала 30 місце, а у 2015 році перемістилася на 38. Безперечно, збільшення тривалості повної середньої освіти до 12 років покращить рейтинг України, але більш важливим $€$ покращення не тривалості, а якості освіти шляхом реформування на підставі виважених рішень. Належна освіта є передумовою для зростання доходів та життєвого рівня окремої особи i, в результаті, сприяє підвищенню якості робочої сили в країні в цілому та $є$ фактором прискореного соціально-економічного розвитку [2].

Основна частина. Мета роботи - проаналізувати стан та перспективи реформування вищої освіти в Україні.

Базовим напрямом реформування вищої освіти в Україні є впровадження принципів Болонського процесу, який було започатковано у 1998 році в Парижі з підписання міністрами освіти Великобританії, Франції, Італії, Бельгії та Німеччини так званої

() В. В. Шухтін, С. Г. Котюжинська, Т. Л. Лєбєдєва, І. М. Шухтіна 
Сорбонської декларації, яка визначила необхідність будувати та підсилювати інтелектуальну, культурну, соціальну і технічну базу Європи [3]. Приєднання України до Болонського процесу відбулося на міжнародній конференції в Бергені (Норвегія) 19 травня 2005 р. [4].

Впровадження Болонського процесу у вищу школу України відбувалося з виданням наказів та листів МОН України [5-12], постанов Кабінету Міністрів України [13, 14], але значний крок у цьому напрямі було зроблено лише з виданням Закону України “Про вищу освіту” [15].

Цей Закон надав правові засади впровадження у повному обсязі Болонського процесу у вищу школу України. В ньому визначається 5 рівнів вищої освіти (початковий, перший, другий, третій та науковий) з присудженням відповідних ступенів молодший бакалавр, бакалавр, магістр, доктор філософії та доктор наук, впроваджується кредитна накопичувальна система та додаток до диплома європейського зразка, вводяться стандарти вищої освіти та система забезпечення якості вищої освіти, підвищується автономність вищих навчальних закладів та роль студентського самоврядування, наголошується необхідність формування замовлення на підготовку кадрів за потребами економіки країни, створюються засади міжнародного співробітництва тощо. Разом з тим Закон має ряд недоліків та прогалин, які мають бути усунені шляхом внесення напрацьованих змін. Це стосується зменшення навантаження на науково-педагогічного працівника шляхом скорочення аудиторних занять, суперечливою $є$ теза про обрання посадових осіб вищого навчального закладу лише на два терміни [16]. Потребує коригування і чинна нормативна база, оскільки у Класифікаторі професій ДК 003:2010 (зі змінами) відсутній ступінь освіти “молодший бакалавр”, тому, наприклад, посаду медичної сестри може посідати особа зі ступенем “молодший спеціаліст” або “бакалавр” [17].

Загалом для реалізації положень цього закону у повному обсязі повинен пройти деякий час. Це обумовлюється багатьма причинами. Так, державні стандарти вищої освіти застаріли і потребують перегляду та запровадження новітніх методик i форм навчання. Підходи до розробки державних стандартів затверджені ще у 1998 р. і після прийняття нової редакції Закону України “Про вищу освіту” не переглядались. Процедури зі створення і впровадження стандартів освіти, контролю їх виконання є достатньо розмитими і приводять до по- двійності підпорядкування і управління, відсутні системні уявлення про об’єкти стандартизації медичної освіти, а та частина державних стандартів, яка існує, потребує подальшого розповсюдження на інші ступені освіти (інтернатуру, магістратуру, клінічну ординатуру). Крім того, практично не розроблена та частина стандартів, яка стосується матеріально-технічного забезпечення та практичної підготовки фахівців з охорони здоров'я [18]. Необхідна розробка та впровадження таких інноваційних форм організації та методик навчального процесу, як самопідготовка та дистанційні методи навчання. Як свідчать результати опитування, підготовка молодих спеціалістів у медичних навчальних закладах потребує значного удосконалення, оскільки близько 40 \% опитаних головних лікарів відмітили, що підготовка молодих спеціалістів (вищого і середнього рівнів освіти) є недостатньою для ефективної роботи у їхньому закладі, їх підготовка відбувається виключно на робочому місці [19]. За інформацією, наведеною у проекті “Стратегії реформування вищої освіти в Україні до 2020 року”, за якістю системи освіти в цілому наша країна посідає 72 місце [20].

Для розвитку мобільності студентів та викладачів, в першу чергу, необхідно знання англійської мови на рівні не менше В2, що і наголошується на законодавчому рівні. Але для цього, по-перше, необхідно забезпечити доступність такого рівня навчання, у тому числі і на кафедрах іноземних мов у вищих навчальних закладах з правом надання їм права видавати відповідні сертифікати. I, по-друге, повинно бути фінансове забезпечення такої мобільності, оскільки рівень стипендій та заробітних плат науково-педагогічних працівників не тільки не дає можливості виїзду за власний кошт за кордон, але й публікації наукових статей за кордоном, оскільки оплата публікацій в іноземних журналах становить не менше 200 доларів США. Але стратегія на 100 \% знання іноземної мови фахівцями вищих ступенів освіти матиме і негативні наслідки. За даними літератури, на сьогодні українці є найчисельнішою групою легальних трудових мігрантів у країнах ЄС, а серед людей віком від 20 до 35 років 42 \% становлять особи з базовою та повною вищою освітою [21]. За умови засвоєння студентами та аспірантами іноземної мови на рівні не менше В2 цей відсоток збільшиться до 100 і країна залишиться без перспективи змінити існуюче економічне становище.

На сьогодні планування підготовки спеціалістів у вищих навчальних закладах, виходячи з потреб 
вітчизняної економіки, неможливо через її стан, оскільки, за відомостями Державної служби статистики України, у січні - вересні 2015 року лише транспорт, складське господарство, поштова та кур’ єрська діяльність і освіта мали позитивний фінансовий результат, усі інші мали негативне сальдо [22]. Окрім того, відсутня зацікавленість підприємців у прийнятті на роботу молодих спеціалістів. Для цього потрібно введення, наприклад, податкових пільг для підприємств і установ, які приймають на роботу випускників вищих навчальних закладів.

Ще однією проблемою у працевлаштуванні випускників медичних вищих навчальних закладів $є$ реформування системи охорони здоров’я. Так, відповідно до наказу МОЗ України від 01.02.2016 р. № 51 кількість лікарняних ліжок на 100 тисяч населення повинно бути зменшено до 60 [23]. За інформацією Державної служби статистики України, у 2014 році цей показник складав 78,5 [24]. Оскільки штат лікарів обумовлюється кількістю лікарняних ліжок [25], то це обумовлює скорочення штатних розкладів лікарняних закладів і вивільнення лікарів, що вже працюють. Наприклад, згідно з бюджетною програмою на 2015 рік за КПКВ 2301070 “Підготовка і підвищення кваліфікації медичних та фармацевтичних, наукових та науково-педагогічних кадрів вищими навчальними закладами III і IV рівнів акредитації” кількість випускників денної форми навчання, підготовка яких здійснювалась за рахунок коштів загального фонду Державного бюджету, становила 3659 осіб, що повинні бути працевлаштовані [26]. Окрім того, повинні були закінчити ВНЗ ще 7758 осіб, які навчались за рахунок спеціального фонду і яких держава не зобов’язана працевлаштовувати. В умовах скорочення досвідчених лікарів їх працевлаштування за спеціальністю вельми проблематичне. Одним з важливих елементів Болонського процесу є надання рівних можливостей в отриманні вищої освіти усім соціальним групам населення. Згідно з пунктом 17 статті 44 Закону України “Про вищу освіту” державна цільова підтримка для здобуття вищої освіти надається у вигляді: повної або часткової оплати навчання за рахунок коштів державного та місцевих бюджетів; пільгових довгострокових кредитів для здобуття освіти та соціальної стипендії. Згідно з проектом “Стратегії реформування вищої освіти в Україні до 2020 року” фінансування навчання певної кількості здобувачів вищої освіти пропонується здійснювати шляхом:

1. Блочного фінансування. Передбачає визначення обсягу державного фінансування ЗВО за форму- лою відповідно до якісних і кількісних показників його діяльності. ЗВО самостійно визначають обсяги прийому за певними спеціальностями здобувачів вищої освіти, навчання яких оплачується за рахунок коштів державного бюджету. Формула розраховує не абсолютний розмір коштів, а відносний показник у межах видатків державного бюджету.

2. Ваучерного фінансування. Здобувач вищої освіти (вступник) отримує право на оплату певної суми за його навчання у ЗВО залежно від результатів ЗНО за курс середньої школи з коштів державного бюджету. Кошти гранту щорічно перераховуються до ЗВО за місцем його успішного навчання.

3 урахуванням потреб молоді, ринку праці та суспільства мають бути такі види ваучерів, як: звичайний ваучер, річна вартість якого дорівнює середній вартості одного року навчання; повний ваучер, річна вартість якого дорівнює максимальній вартості одного року навчання у ЗВО України; спеціальний ваучер, який призначається для оплати навчання за окремими важливими для суспільства i держави спеціальностями 3 високою вартістю навчання (наприклад, окремі інженерні спеціальності, металургія, хімія тощо); соціальний ваучер, який призначається для навчання соціально незахищених осіб; зокрема, може бути використаний для проходження підготовчих відділень з метою успішного складання ЗНО.

3. Кредитної системи фінансування - система видачі державою через державні банки (або створення національного банку кредитування освіти) безвідсоткових кредитів (або з відсотком, який буде дорівнювати рівню інфляції) на будь-яку форму навчання з відстрочкою погашення на період навчання, строком на 10-15 років. Договір має тристоронній характер: кредитна установа - здобувач вищої освіти - ЗВО. При цьому держава бере на себе всі ризики, пов’ язані з неможливістю здобувача вищої освіти виплачувати кредит. Кредит може виплачуватись здобувачем вищої освіти, роботодавцем або через податкові відрахування. Виплати можуть розраховуватись від розміру майбутніх доходів. Кредит може покривати не тільки вартість навчання, а і всі інші суміжні витрати (дослідження, проживання, підручники, харчування, проїзд тощо), що дає більше можливостей малозабезпеченим дітям [20].

Згідно з пунктом 8 статті 72 фінансування за рахунок видатків Державного бюджету України підготовки фахівців з вищою освітою за спеціальностями відповідних ступенів вищої освіти встановлюється в обсязі, необхідному для забезпечення 
на кожні 10 тисяч населення навчання не менше 180 студентів. Згідно з відомостями Державної служби статистики України у 2015 році налічувалось 1605,3 тисячі студентів ВНЗ усіх рівнів акредитації. Оскільки кількість населення в Україні у 2015 році налічувала 42 929,3 тисячі осіб, то у перерахунку на 10 тисяч населення це 374 студенти, а оскільки менше половини з них навчається за рахунок загального фонду Державного бюджету, то на сьогодні вже забезпечується виконання За- кону України “Про вищу освіту” в цілому. Якщо ж враховувати спеціальності і ступені освіти, то цей показник буде значно нижчим. Теза про те, що кількість студентів українських ВНЗ значно перевищує рівень розвинених країн і нам не потрібна у сучасних економічних умовах така кількість людей з вищою освітою, що неодноразово обгрунтовувалась у засобах масової інформації, не відповідає дійсності. По-перше, за кількістю студентів незначно переважає розвинені країни світу (табл. 1).

Таблиця 1. Кількість студентів на 10 тис. населення у 2012 році

\begin{tabular}{|l|c|c|c|}
\hline \multicolumn{1}{|c|}{ Країна } & Кількість населення & $\begin{array}{c}\text { Кількість студентів, } \\
\text { які навчаються у ВН3 }\end{array}$ & $\begin{array}{c}\text { Кількість студентів } \\
\text { на 10 тис. населення }\end{array}$ \\
\hline Великобританія & 63181775 & 3582166 & 467 \\
\hline Австралія & 23365337 & 1088366 & 398 \\
\hline Франція & 65806000 & 2616643 & 370 \\
\hline США & 317579000 & 11748263 & 329 \\
\hline Німеччина & 80548000 & 2645504 & 288 \\
\hline Японія & 127253075 & 3670435 & \\
\hline
\end{tabular}

По-друге, на сьогодні до вищої освіти відноситься і підготовка фахівців середньої ланки - техніків, механіків, диспетчерів, фармацевтів, лаборантів, медичних сестер тощо, необхідність у наявності яких не викликає сумніву. По-третє, лише наявність у країні значної кількості фахівців з якісною повною вищою освітою є передумовою економічного розвитку України. Безперечно, надмірна кількість юристів та економістів не потрібна, але, зважаючи на позитивне рішення про подовження терміну дії результатів зовнішнього незалежного оцінювання на 2-3 роки, що надає молоді можливість більш виважено підійти до вибору майбутньої професії, доцільно було б скасувати термін дії цих результатів при отриманні другої вищої освіти. Отримані ж людиною юридичні та економічні знання не завадять у будь-якій професіі. Не викликає сумніву, що державні кошти слід витрачати на підготовку фахівців виходячи з потреб економіки країни, але скасовувати пільгові умови вступу до ВНЗ та можливість безоплатного навчання незахищених верств населення, як то передбачає законопроект № 3628, суперечить одному з основних положень Болонського процесу щодо доступності вищої освіти для всіх [27].

Впровадження ваучерної системи навчання було б доречним, якщо з неї виключити можливу корупційну складову. А навчання шляхом отримання кредиту може бути впроваджено лише у далекій перспективі, оскільки при нинішньому економічному стані коштів у держави на такі кредити немає, а при нинішньому рівні заробітної плати, зокрема медичних працівників, якщо враховувати не тільки вартість навчання, а і всі інші суміжні витрати (дослідження, проживання, підручники, харчування, проїзд тощо), випускники із малозабезпечених сімей передадуть погашення цього кредиту своїм дітям.

Одним із пріоритетних напрямів реформування вищої освіти є покращення її якості, у тому числі за рахунок скорочення кількості ВНЗ шляхом або їх об’єднання, або закриття. У своєму інтерв'ю перший заступник міністра освіти і науки I. Совсун зазначила, що бажано скоротити кількість ВНЗ до 150 [28]. Найчастіше необхідність скорочення кількості ВНЗ обгрунтовується посиланням на європейські країни, де кількість ВНЗ у перерахунку на населення значно нижче, ніж в Україні. Але згідно $з$ даними літератури Україна знаходиться серед країн Європи та СНД на 37 місці з 55 країн ЄС та СНД і має теж співвідношення, що й в середньому по 28 країнах ЄС (табл. 2).

Тому рішення щодо напрямів реформування вищої освіти в Україні повинні базуватись не на адміністративних рішеннях, а виважених рішеннях на базі наукових дослідженнях наявних та перспективних потреб у робочій силі відповідної кваліфікації, а програми їх підготовки узгоджуватись з рівнем компетенції, які вимагають роботодавці, оскільки, як свідчать дані літератури, останніми роками роботодавці все частіше зазначають високий освітній рівень претендентів на робочі місця, який однак у 
Таблиця 2. Кількість населення, що припадає на 1 ВНЗ у 2013 році

\begin{tabular}{|c|l|c|c|c|}
\hline Рейтинг & \multicolumn{1}{|c|}{ Країна } & Кількість Н3 & Кількість населення & Населення на ВН3 \\
\hline 1 & Ліхтенштейн & 3 & 37007 & 12336 \\
\hline 6 & Латвія & 56 & 2178443 & 38901 \\
\hline 11 & Данія & 84 & 5556452 & 66148 \\
\hline 17 & Швейцарія & 104 & 7996026 & 110472 \\
\hline 27 & Франція & 597 & 65951611 & 123938 \\
\hline 32 & Чехія & 82 & 10162921 & 145664 \\
\hline 37 & Україна & 306 & 44573205 & 199870 \\
\hline 43 & Німеччина & 406 & 81147265 & 205830 \\
\hline 45 & Великобританія & 308 & 63395574 & 261627 \\
\hline 50 & Італія & 235 & 61482297 & 143281 \\
\hline
\end{tabular}

більшості випадків не характеризується набором компетенцій, необхідних підприємствам [17].

Висновок. Безперечно, Закон України “Про вищу освіту” є значним кроком у входженні нашої держа-

\section{Список літератури}

1. Моніторинг інтеграції української системи вищої освіти в Європейський простір вищої освіти та наукового дослідження: моніторинг. дослідж. : аналіт. звіт / Міжнарод. благод. фонд “Міжнарод. фонд дослідж. освіт. політики” ; за заг. ред. Т. В. Фінікова, О. І. Шарова. - К. : Таксон, 2014. - 144 с. - Бібліогр.: с. 130-143.

2. Рєвнівцева О. В. Система вищої освіти України: фінансові аспекти сучасних проблем розвитку / О. В. Рєвнівцева // Демографія та соціальна економіка. - 2010. № 2 (14). - С. 36-45.

3. Совместная декларация о гармонизации архитектуры европейской системы высшего образования четырех министров, представляющих Великобританию, Германию, Францию и Италию (г. Париж, Сорбонна, 25 мая 1998 года) [Электронный ресурс]. - Режим доступа : http:// www.france-jus.ru/upload/docs/Declaration_Sorbonne.pdf.

4. Зона европейского высшего образования. Совместное заявление европейских министров образования (г. Болонья, 19 июня 1999 года) [Электронный ресурс]. Режим доступа : http://pehea.in.ua/sites/default/files/ documents/2014/10/07/2._bolonskaya_deklaraciya_1999. pdf.

5. Наказ МОН України від 23.01.2004 р. № 48 “Про проведення педагогічного експерименту з кредитномодульної системи організації навчального процесу” [Електронний ресурс]. - Режим доступу : http://old.mon. gov.ua/images/files/osvita/evrointehraciya/mon_48.doc.

6. Наказ МОН України від 20.10.2004 р. № 812 “Про особливості впровадження кредитно-модульної системи організації навчального процесу” [Електронний ресурс]. - Режим доступу : http://old.mon.gov.ua/images/ files/osvita/evrointehraciya/mon_812.doc.

7. Наказ МОН України від 30.12.2005 р. № 774 “Про впровадження кредитно-модульної системи організа- ви до європейської спільноти, але реальне втілення його положень можливе лише за умови наукового обгрунтування заходів з реформування та значного економічного зростання країни.

ції навчального процесу” [Електронний ресурс]. - Режим доступу : http://old.mon.gov.ua/images/files/osvita/ evrointehraciya/mon_774.doc.

8. Наказ МОН України від 16.10.2009 р. № 943 “Про запровадження у вищих навчальних закладах України Європейської кредитно-трансферної системи” [Електронний ресурс]. - Режим доступу : http://old.mon.gov.ua/ images/files/osvita/evrointehraciya/943.doc.

9. Спільний наказ МОНмолодьспорт України та Мінсоцполітики України від 20.04.2012 р. № 488\225 “Про затвердження плану заходів щодо впровадження Національної рамки кваліфікацій” [Електронний ресурс]. Режим доступу : http://old.mon.gov.ua/images/files/osvita/ evrointehraciya/488.doc.

10. Лист МОН України від 26.02.2010 р. № 1/9-119 “Про методичні рекомендації щодо запровадження Європейської кредитно-трансферної системи та її ключових документів у вищих навчальних закладах" [Електронний ресурс]. - Режим доступу : http://old.mon.gov.ua/images/ files/osvita/evrointehraciya/list_mon_119.doc.

11. Лист МОН України від 10.06.2010 р. № 1/9-409 “Щодо запровадження Додатка до диплома європейського зразка” [Електронний ресурс]. - Режим доступу : http://old.mon.gov.ua/images/files/osvita/ evrointehraciya/1_9_409.doc.

12. Лист МОН України від 08.02.2016 р. № 1/9-67 “Про завершення верифікації переліку спеціальностей, з яких вищі навчальні заклади готові в 2016 році здійснювати прийом здобувачів вищої освіти ступеня бакалавра (магістра і спеціаліста медичного, фармацевтичного та ветеринарного спрямувань) на основі повної загальної середньої освіти за бюджетні кошти” [Електронний ресурс]. - Режим доступу : http://old.mon.gov.ua/ua/aboutministry/normativ/5068. 
13. Постанова Кабінету Міністрів України від 29.12.2010 р. № 1225 “Про утворення міжвідомчої робочої групи з питань розроблення та впровадження Національної рамки кваліфікацій” [Електронний ресурс]. Режим доступу : http://old.mon.gov.ua/images/files/osvita/ evrointehraciya/1225.doc.

14. Постанова Кабінету Міністрів України від 23.11.2011 р. № 1343 “Про затвердження Національної рамки кваліфікацій” [Електронний ресурс]. - Режим доступу : http://old.mon.gov.ua/images/files/osvita/ evrointehraciya/1341.rar.

15. Закон України “Про вищу освіту” від 01.07.2014 р. № 1556-VII (зі змінами) [Електронний ресурс]. - Режим доступу : http://zakon5.rada.gov.ua/laws/show/1556-18.

16. Русин М. О. Етапи регулювання вищої освіти в Україні в період незалежності / М. О. Русин // Порівняльно-аналітичне право. - 2015. - № 4. - С. 274-277.

17. Ільїч Л. М. Узгодження кваліфікацій з урахуванням потреб ринку праці: проблеми та шляхи розв’язання / Л. М. Ільїч // Демографія та соціальна економіка. - 2015. № 3 (25). - С. 173-184.

18. Басій Р. В. Стандартизація медичної освіти як проблема державного управління в Україні / Р. В. Басій // Публічне управління: теорія та практика. - 2013. - Вип. 4. С. 232-237.

19. Аналітичний звіт за результатами дослідження: “Оцінка потенціалу існуючої системи медичної освіти/професійного розвитку (CME/CPD) для фахівців, що працюють у сфері профілактики, діагностики та лікування ВІЛ-інфекції/СНІДу”. - К., 2015. - 169 с. [Електронний ресурс]. - Режим доступу : http://www. hivreforminaction.org/wp-content/uploads/2015/10/CMECPD-Ukr1.pdf.

20. Стратегія реформування вищої освіти в Україні до 2020 року (проект). - К., 2014. - 75 с. [Електронний ресурс]. - Режим доступу : http://www.tnpu.edu.ua/EKTS/ strate2014.pdf.
21. Романюк М. Д. Міграційні загрози національній безпеці України: сучасні виклики, проблеми подолання / М. Д. Романюк // Демографія та соціальна економіка. 2015. - № 3 (25). - С. 99-111.

22. Статистична інформація “Фінансові результати великих та середніх підприємств до оподаткування за видами економічної діяльності за січень - вересень 2015 року” [Електронний ресурс]. - Режим доступу : www. ukrstat.gov.ua.

23. Наказ МОЗ України від 01.02.2016 р. № 51 “Про затвердження Методики щодо забезпечення стаціонарними лікарняними ліжками у розрахунку на 10 тис. населення” [Електронний ресурс]. - Режим доступу : http:// zakon3.rada.gov.ua/laws/show/z0269-16.

24. Статистична інформація “Заклади охорони здоров'я” [Електронний ресурс]. - Режим доступу : www.ukrstat.gov.ua.

25. Наказ МОЗ України від 23.02.2000 р. № 33 “Про штатні нормативи та типові штати закладів охорони здоров'я” (зі змінами) [Електронний ресурс]. - Режим доступу : http://www.moz.gov.ua/ua/portal/ dn_20000223_33n.html.

26. Постанова Кабінету Міністрів України від 22 серпня 1996 р. № 992 “Про Порядок працевлаштування випускників вищих навчальних закладів, підготовка яких здійснювалась за державним замовленням” [Електронний ресурс]. - Режим доступу : http://zakon3.rada.gov. ua/laws/show/992-96-\%D0\%BF.

27. Законопроект № 3628 “Про внесення змін до деяких законодавчих актів України (щодо стабілізації фінансового стану держави та удосконалення окремих положень соціальної політики)” [Електронний ресурс]. Режим доступу : http://w1.c1.rada.gov.ua/pls/zweb2/web proc4_2?id=\&pf3516=3628\&skl=9.

28. Інтерв'ю першого заступника Міністра освіти і науки України Інни Совсун інформаційному агентству “Українські новини”, 22.12.2015 р. [Електронний ресурс]. - Режим доступу : http://ukranews.com/ interview/2015/12/22/685. 